\title{
Macroalgal community response to re-oligotrophication in Saronikos Gulf
}

\author{
Konstantinos Tsiamis ${ }^{1,2, *}$, Panayotis Panayotidis ${ }^{1}$, Maria Salomidi ${ }^{1}$, \\ Alexandra Pavlidou ${ }^{1}$, Julia Kleinteich ${ }^{3}$, Katerina Balanika ${ }^{1,2}$, Frithjof C. Küpper ${ }^{4,5}$ \\ ${ }^{1}$ Hellenic Centre for Marine Research (HCMR), Institute of Oceanography, Anavyssos 19013, Attica, Greece \\ ${ }^{2}$ Faculty of Biology, Department of Ecology and Taxonomy, Athens University, Panepistimiopolis 15784, Athens, Greece \\ ${ }^{3}$ Human and Environmental Toxicology, Department of Biology, University of Konstanz, 78457 Konstanz, Germany \\ ${ }^{4}$ Scottish Association for Marine Science, Scottish Marine Institute, Oban, Argyll PA37 1QA, UK \\ ${ }^{5}$ Oceanlab, University of Aberdeen, Main Street, Newburgh, Aberdeenshire AB41 6AA, UK
}

\begin{abstract}
The Saronikos Gulf, an embayment of the Aegean Sea (Greece, Eastern Mediterranean), has undergone profound and unprecedented environmental changes due to the rapid urbanization of the Athens-Piraeus metropolitan area since the 1950s. From the mid-1950s until the mid1990s, the inner part of Saronikos Gulf was subject to increasing inputs of untreated urban sewage. The resulting long-lasting eutrophication was reflected in the phytobenthos by the presence of low-diversity, mainly ephemeral species communities, largely dominated by the nitrophilous green algae Ulva spp. and Cladophora spp. In the mid-1990s, a wastewater treatment plant started operating on Psittalia islet near the port of Piraeus, capturing the entire central sewage outfall of Athens. Since 1998, the coastal ecosystem of Saronikos Gulf has been under regular monitoring to assess intra-annual and interannual changes in benthic macroalgal communities and nutrient levels. A sharp decline in nutrient and organic loads was soon recorded, leading to a rapid re-oligotrophication of the gulf. Upon this new regime shift, macroalgal communities responded by a general increase in biodiversity and a marked decrease in the abundance of nitrophilous green algae. Within the last years, however, the canopy brown algae (Cystoseira and Sargassum) in the area unexpectedly showed a sharp population decline. Even though this phenomenon may be still ongoing and thus is not fully described and understood, this study is the first to provide a long-term data set of macroalgal responses to a rapid re-oligotrophication process taking place within a highly urbanized Mediterranean coastal area.
\end{abstract}

KEY WORDS: Macroalgae - Greece - Eastern Mediterranean - European Water Framework Directive $\cdot$ Phytobenthos $\cdot$ Cystoseira $\cdot$ Ulva

\section{INTRODUCTION}

Marine macroalgal vegetation can be affected by various factors in the coastal zone, including changes in nutrient levels (Munda \& Veber 1996), sea urchin grazing (Thibaut et al. 2005) as well as competition by alien species (Williams \& Smith 2007). Alterations of macroalgal community structure and composition as well as biodiversity loss due to high nutrient loads are well-documented and widespread phenomena
(Arévalo et al. 2007). For this reason, studies on marine macroalgae, particularly those in shallow waters, have been traditionally used to detect and evaluate anthropogenic effects on coastal ecosystems (Littler \& Murray 1975, Tewari \& Joshi 1988).

The macroalgal flora of the Mediterranean Sea is characterized by high biodiversity (Coll et al. 2010) as it consists of various phytogeographic elements, mainly of warm-temperate (chiefly Atlantic) and tropical (chiefly Indo-Pacific) affinities (Bianchi \& 
Morri 2000). Large kelps of the Laminariales, which are typical of temperate coastal ecosystems throughout the world, are scarce in the Mediterranean Sea (Steneck et al. 2002). Here, their canopy-forming role is instead fulfilled by Cystoseira and Sargassum (Fucales), the former exhibiting particularly high Mediterranean speciation (Roberts 1978). Cystoseira and Sargassum communities have long been considered the climax stage of the shallow-water Mediterranean rocky shores (Pérès \& Picard 1964), but their role in structuring entire communities of high biodiversity in deeper environments is increasingly recognized (Hereu et al. 2008). These perennial erect species are known to characterize the pristine, oligotrophic Mediterranean coasts (Pergent 1991), and show high sensitivity to natural and human disturbances (Hoffman et al. 1988, Rodriguez-Prieto \& Polo 1996, Thibaut et al. 2005). In contrast, opportunistic nitrophilous green algae, such as species of the genera Ulva and Cladophora, commonly thrive in organically enriched ecosystems (Belsher 1977, Diez et al. 1999), and they have been repeatedly documented to gradually outcompete and replace Cystoseira species under increasing nutrient loads (Pergent 1991, Soltan et al. 2001, Panayotidis et al. 2004). On these grounds, marine macroalgae, particularly those of the upper infralittoral zone, are commonly used as indicators of marine ecosystem quality (Soltan et al. 2001, Orlando-Bonaca et al. 2008, Orfanidis et al. 2011), and are thus included among the 4 main biological quality elements that need to be monitored for the purposes of the European Water Framework Directive (2000/ 60/EC) (Panayotidis et al. 2004).

Here we present the long-term changes in the marine vegetation and nutrient levels of the Saronikos Gulf (Greece, Eastern Mediterranean Sea) following the start of operations of the Psittalia Wastewater Treatment Plant (WWTP), which has been serving the wider Athens-Piraeus urban area since 1998. Based on a large time series of seasonal macroalgal surveys within a period of over $10 \mathrm{yr}$ (from 1998 to 2010), we reveal a gradual recovery of macroalgal communities in response to decreasing levels of eutrophication. While several studies have investigated the impact of sewage disposal and consequent organic enrichment on macroalgal communities (e.g. Brown et al. 1990), few have actually focused on the reverse effects caused by re-oligotrophication processes (Diez et al. 2009). This is the first such study in the Mediterranean Sea, which should have a wider relevance due to the need to mitigate coastal pollution impacts stemming from the massive and ongoing urbanization along most Mediterranean and other shores worldwide.

\section{MATERIALS AND METHODS}

\section{The study region}

The Saronikos Gulf is one of the largest embayments of the South Aegean Sea, surrounded by the peninsulas of Attica in the north and the NE Peloponnissos in the south. The gulf contains several islands and islets, Salamina and Aegina being the most important in terms of size and population density. Along the northern shores of Saronikos lies the capital city of Greece, the Athens-Piraeus metropolitan area, which, although inhabited since ancient times, has faced a rapid and largely uncontrolled urbanization since the 1950s. Within just the last decades the population of the larger Athens urban zone has grown to $\sim 5$ million (Pavlidou \& Kapari 2010), leading to a subsequent dramatic increase in resource use and environmental effects. Among the major human activities that directly affect the coastal marine ecosystem of the Saronikos Gulf are the rapid and extensive modification of the coastline, the industrial pollution from oil refineries and metallurgy, and the strong pressures resulting from the increasing recreational and fishing activities. National and international shipping and ship-building activities around Piraeus, one of the largest ports in the Mediterranean Sea and the world, are also considerable pollution sources in this area. Moreover, the gulf is subject to an unprecedented introduction of alien species, largely due to the area's intense maritime traffic and the Lessepsian (i.e. through the Suez Canal) immigration phenomenon, which has been strongly affecting the wider Eastern Mediterranean basin during the last 2 decades (Tsiamis et al. 2010). However, urban sewage discharge, with an estimated average outflow of $750000 \mathrm{t} \mathrm{d}^{-1}$ (Xenarios 2009), is thought to impose the most significant stress on the marine environment of the gulf, causing a clear pollution gradient along its coasts (Simboura et al. 2005).

Sporadic surveys of macroalgae of Saronikos Gulf were performed as early as the 1910s, mentioning the presence of Cystoseira discors and Ulva lactuca among other species (Petersen 1918). The French RV 'Calypso' cruise in 1955 explored the inner Saronikos Gulf (off Salamina Island) just before the onset of the massive urbanization of the area, and recorded the sporadic presence of Hydroclathrus clathratus in the upper infralittoral zone, surrounded by a belt of Cystoseira compressa at its lower margin (Pérès \& Picard 1956). In the early 1980s, Diapoulis \& Haritonidis (1987) reported a relative abun- 
dance in nitrophilous green algae and a scarcity of Cystoseira species, which was attributed to eutrophic conditions of the inner gulf. More recently, assessment of the macroalgal vegetation of Saronikos Gulf through biodiversity surveys and the application of the ad hoc Ecological Evaluation Index (Orfanidis et al. 2001) has served as a pilot study case to test the applicability of the main biological quality elements of the European Water Framework Directive (Simboura et al. 2005).

Up until 1994, the entire untreated sewage of the larger Athens urban zone had been disposed of in the surface waters near the uninhabited islet of Psittalia, resulting in a steep pollution gradient (Makra et al. 2001). In 1994, with the construction of the Psittalia WWTP (Fig. 1), sewage started receiving primary treatment, with disposal into deeper water $(63 \mathrm{~m})$ through multi-port diffusers. During a 4 yr test period, the Psittalia WWTP operated at intervals and with partial capacity until 1998, when it became fully operational. Since late 2004, the sewage has also been undergoing secondary treatment with the objective to further remove the organic nitrogen and reverse the increasing marine eutrophication trends of recent decades. Since 1998, the marine environment surrounding the Psittalia WWTP project has been seasonally and inter-annually monitored in order to assess inter alia its short- and long-term effects on macroalgal populations and seawater nutrient levels in the Saronikos Gulf.

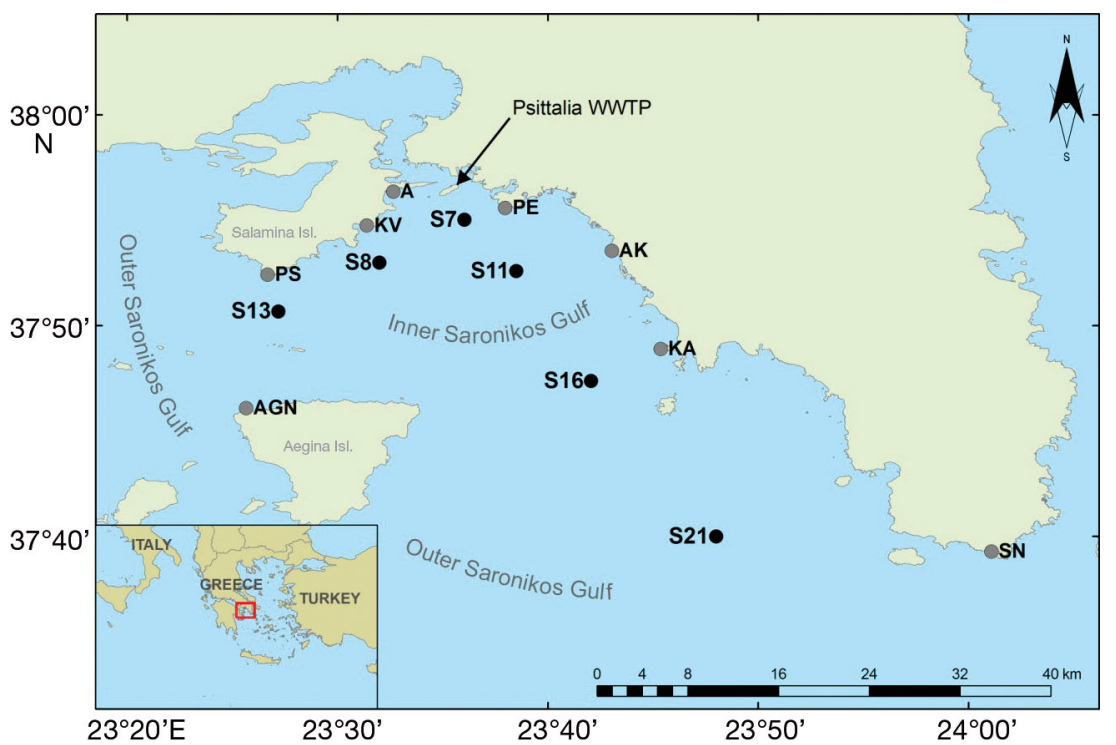

Fig. 1. Inner and outer Saronikos Gulf sampling sites for macroalgae $\left(O_{i} \mathrm{SN}\right.$ : Sounio; KA: Kavouri; AK: Agios Kosmas; PE: Peiraiki; A: Ampelakia; KV: Kaki Vigla; PS: Peristeria; AGN: Aegina Isl.) and nutrients (1, S7, S8, S11, S13, S16, and S21). Arrow: location of the Psittalia Wastewater Treatment Plant (WWTP)

\section{Macroalgal sampling and laboratory analysis}

Along the rocky coasts of Saronikos Gulf, 8 sampling stations were chosen (Fig. 1), situated on 2 axes with increasing distance from Psittalia WWTP. The density of stations was higher in close proximity to the Psittalia islet. All sampling stations are characterised by smooth rocky shores with moderate hydrodynamic conditions, which are typical of this area. Sampling stations are divided into 2 major groups: the Kaki Vigla, Ampelakia, Peiraiki, and Agios Kosmas sites are situated in the inner, most enclosed part of the gulf, and are more directly affected by the sewage outfall, while the Aegina Island, Peristeria, Kavouri, and Sounio sites represent the outer (i.e. the more distant and more open) part of the gulf, which is less affected (Fig. 1). Two seasonal samplings (March and September) were carried out annually from 1998 to 2010, with an exception for years 2000 and 2004 due to logistical constraints.

Macroalgal samples were collected by free diving along the upper rocky infralittoral, from almost horizontal surfaces, $30-50 \mathrm{~cm}$ below the lowest water level. Macroalgae in one quadrat of $400 \mathrm{~cm}^{2}(20 \times$ $20 \mathrm{~cm}$ ), which is considered to be the minimal representative sampling surface for the Mediterranean infralittoral communities (Dhont \& Coppejans 1977, Boudouresque \& Belsher 1979), were scraped off with a chisel at each site and season. Each quadrat corresponded to one sampling unit. The material collected was preserved in buffered $4 \%$ formalin/seawater.

In the laboratory, specimens were observed under dissecting or compound microscopes. When necessary, they were sectioned manually with a razor blade. Species were identified down to the lowest possible taxonomic level, and the abundance of each taxon was estimated as percent coverage in the sampling surface $\left(4 \mathrm{~cm}^{2}=1 \%\right)$ in horizontal projection (Verlaque 1987). All taxon-specific coverage values were estimated for each sampling unit (quadrat). The cumulative coverage of taxa per sampling unit would often exceed $100 \%$ due to multiple layers of vegetation (canopy, bushy, epiphytes). Taking into account each taxon coverage value for each sampling unit, an overall data set was created for all sampling units, containing all taxa identified and their coverage values per unit. 
Finally, photomicrographs and measurements were taken using a Leitz Ortholux microscope fitted with an Olympus $\mu 1030$ SW camera. For nomenclature purposes the following taxonomic databases were used: Index Nominum Algarum (Silva 2011) and AlgaeBase (Guiry \& Guiry 2011).

\section{Nutrient sampling and laboratory analysis}

Nutrient data were obtained through seasonal or monthly cruises (4-12 samplings per year) for the period 1998 to 2010 (109 cruises in total), using either small inflatable boats or the RVs 'Aegaio' and 'Filia' of the Hellenic Centre for Marine Research. Six sampling stations were monitored, among which S7, S8 and S11 are representative of the inner, and S13, S16 and S21 of the outer Saronikos region (Fig. 1). At the selected stations, surface seawater samples were collected with Niskin bottles, either mounted on a rosette or individually on a hydro wire.

Seawater samples for the determination of nutrients were filtered through membrane Millipore filters $0.45 \mu \mathrm{m}$ with a suitable filtration unit (syringe + Swinnex) directly connected to the outlet of the sampling bottle. The filtered seawater was then collected in $100 \mathrm{ml}$ polyethylene bottles 'aged' with $\mathrm{HCl}$ 10\% and rinsed 3 times with deionized water and 3 times with the filtered sample. Seawater samples were collected in triplicate and were kept deep-frozen $\left(-20^{\circ} \mathrm{C}\right)$ until their analysis in the laboratory.

Filtered samples were analyzed with a BRAN+ LUEBBE II autoanalyser according to standard methods for nitrate-nitrite $\left(\mathrm{N}-\mathrm{NO}_{3}+\mathrm{N}-\mathrm{NO}_{2}\right.$; Strickland \& Parsons 1977). Determinations of ammonia nitrogen (N-NH ${ }_{4}$; Koroleff 1970) and soluble reactive phosphorus (SRP) (Murphy \& Riley 1962) were performed using first a Hitachi and afterwards a Perkin Elmer 20 Lambda and 25 Lambda spectrophotometer according to standard methods referred above. The concentration of dissolved inorganic nitrogen $\left(\mathrm{DIN}=\mathrm{N}-\mathrm{NH}_{4}\right.$ $+\mathrm{N}-\mathrm{NO}_{2}+\mathrm{N}-\mathrm{NO}_{3}$ ) was then computed and used for data evaluation and statistical analysis.

\section{Statistical analysis}

An overall algal data set was created for all sampling units (quadrats), containing all taxa identified and their coverage values per sample unit. Based on that data set, specific parameters were calculated: the total number of species and the total coverage of all species per sampling unit. In addition, the cumu- lative coverage of the genera Ulva and Cladophora, hereafter referred to as nitrophilous green algae (NGA), as well as the genera Cystoseira and Sargassum spp., hereafter referred to as canopy brown algae (CBA), were also separately calculated per sample unit. Finally, mean annual nutrient values (DIN and SRP) were estimated for each nutrient sampling station.

The normality of data of each of the above parameters (total number of species, total coverage, NGA coverage, CBA coverage and nutrient values per sampling unit) was tested using the Kolmogorov-Smirnov test and normal probability plots (P-P), while the homogeneity of variances was tested by the Cochran's test. One-way ANOVA was applied on normally distributed data (without transformation), followed by the Student-Newman-Keuls test for a posteriori comparisons of means, aiming to examine differences in each parameter value over different sampling years. In cases of non-normality or heterogeneity of variance the non-parametric Kruskal-Wallis test was applied. All differences were considered significant at $\mathrm{p}<$ 0.05, indicating that there was a statistically significant difference between the mean value from one year to another at $95 \%$ confidence level. All parameters values are expressed in the provided figures as annual means \pm SE for each sampling year.

A non-metric multidimensional scaling (MDS) analysis based on Bray-Curtis similarities was undertaken on the original overall algal coverage data set of all sampling units, which was square-root transformed. The number of restarts was 100 and the results were plotted in 2 dimensions with a stress value of 0.23 . Distances between data points as represented in the plot are thus an indicator of similarity. In addition, SIMPER analysis (similarity percentages, i.e. species contributions) was applied in order to detect dissimilarities in species composition between communities, using the overall coverage data without treatment. The programs STATISTICA StatSoft ${ }^{\mathrm{TM}}$ v.6 and PRIMER v.6.1.8 were used for all statistical analyses.

\section{RESULTS}

\section{Aspects of macroalgal populations}

In total, 213 macroalgal taxa were identified throughout the study area and period (Table S1 in the supplement at www.int-res.com/articles/suppl/ m472p073_supp.pdf), among which 47 belong to Chlorophyta, 36 to Ochrophyta, and 130 to Rhodo- 
phyta. Of these taxa, 7 are reported for the first time from Greece.

Based on their macroalgal features, sampling stations can be separated in 2 distinct groups: those of the outer and those of the inner Saronikos regions (Fig. 2). In general, sites of the outer region were dominated by the CBA Cystoseira crinitophylla and its epiphyte Jania rubens, while sites of the inner region were dominated by the NGA Ulva spp. and the geniculate red alga Corallina elongata (Table 1). However, the macroalgal communities went through several gradual changes throughout the study area and period, all the more pronounced within the inner part of the gulf (Fig. 2).

More specifically, species richness clearly started increasing with the beginning of full operations of the Psittalia WWTP (Fig. 3, Table 2). In particular, in the case of the inner Saronikos, the number of species roughly tripled from 1998 to 2006, and levelled off afterwards (Fig. 3). In contrast, the total vegetation coverage decreased abruptly during the last years of this study, both in the outer and inner Saronikos regions (Fig. 4, Table 2). From 1998 up until 2005, the total coverage values diminished to less than half, levelling off after 2005 (Fig. 4).

Cumulative coverage of NGA showed higher coverage values within the inner region than within the outer region (Fig. 5). NGA abundance in the inner region presented a clear, gradual decrease until 2010, when it reached less than one-third of its original values in 1998 (Fig. 5, Table 2). In the outer region, the NGA coverage was generally characterized by rather low values over the whole study period (Fig. 5). However, a general decrease was also observed over the years in this region, but this trend was far smoother compared with the inner region's dramatic fall (Fig. 5, Table 2).

The decrease of NGA coverage was studied at a seasonal scale, revealing sharp differences between the cold and the warm season in the inner gulf (Fig. 6). During the cold season (March) there was a marked decline of NGA coverage over the years, starting from almost $100 \%$ in 1998 and reaching down to $20 \%$ in 2010 (Figs. 6, 7, Table 3). During the warm season (September), the abundance of NGA was always lower than during the cold seasons. A small and rather smooth
NGA decrease that was observed throughout the warm study periods (Fig. 6) was not found to be statistically significant (Table 3).

The abundance of the CBA Cystoseira and Sargassum spp. changed gradually over the years, especially at outer region sites (Fig. 8). Indeed, a major decline of CBA coverage was observed for the latter, decreasing from $\sim 100 \%$ in 1998 to $40 \%$ in 2010

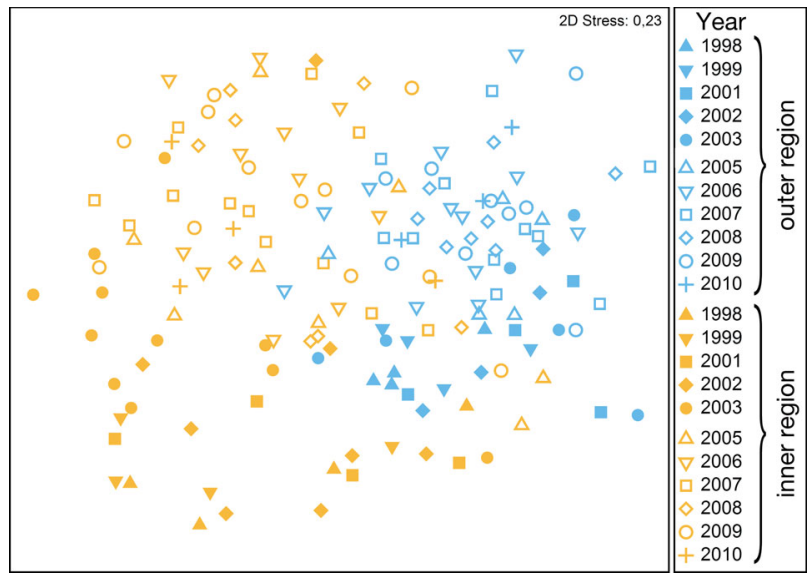

Fig. 2. Community transition before (filled symbols) and after 2004 (open symbols) for the inner (orange) and outer (blue) Saronikos Gulf regions displayed as a non-metric multidimensional scaling (MDS) plot based on Bray-Curtis similarities

Table 1. Differences in abundance of major macroalgal species found in the outer and inner Saronikos Gulf based on similarity percentage analysis (SIMPER). The dissimilarity and the contribution (\%) of each taxon to overall dissimilarity are also given. Averaged values

\begin{tabular}{|lcccc}
\hline $\begin{array}{l}\text { Overall average } \\
\text { dissimilarity = 81.99 }\end{array}$ & $\begin{array}{c}\text { Abundance } \\
\text { Taxon }\end{array}$ & $\begin{array}{c}\text { Dissi- } \\
\text { in Saronikos Gulf } \\
\text { Outer }\end{array}$ & $\begin{array}{c}\text { Inner } \\
\text { Contrib. } \\
\text { (\%) }\end{array}$ \\
\hline Cystoseira crinitophylla & 41.6 & 1.9 & 12.5 & 15.3 \\
Ulva spp. & 6.1 & 27.6 & 7.7 & 9.4 \\
Jania rubens & 22 & 14.8 & 7.1 & 8.7 \\
Corallina elongata & 1.8 & 23.8 & 7.1 & 8.7 \\
Cystoseira compressa & 10.6 & 7.3 & 4 & 4.9 \\
Halopteris scoparia & 7.5 & 8.7 & 3.7 & 4.6 \\
Sargassum vulgare & 10.9 & 6.0 & 3.6 & 4.4 \\
Dictyopteris polypodioides & 4.3 & 8.5 & 3.1 & 3.7 \\
Padina pavonica & 6.8 & 2.3 & 2.3 & 2.8 \\
Dictyota dichotoma & 2.9 & 5.8 & 2.2 & 2.7 \\
Jania virgata & 2.9 & 2.8 & 1.6 & 1.9 \\
Cladophora spp. & 3.5 & 3.1 & 1.5 & 1.8 \\
Schizymenia dubyi & 1.7 & 3.1 & 1.2 & 1.5 \\
Acanthophora nayadiformis & 1.2 & 2.7 & 1.1 & 1.4 \\
Caulerpa racemosa var. cylindracea & 3.1 & 1.1 & 1.1 & 1.4 \\
Halopteris filicina & 2.6 & 0.9 & 1.1 & 1.3 \\
Hypnea musciformis & 0.8 & 3.3 & 1.0 & 1.3 \\
Dictyota sp. & 0.7 & 3.9 & 1.0 & 1.3 \\
Pterocladiella capillacea & 0 & 3.0 & 1.0 & 1.2 \\
Halimeda tuna & 1.6 & 1.7 & 0.9 & 1.1 \\
\hline
\end{tabular}



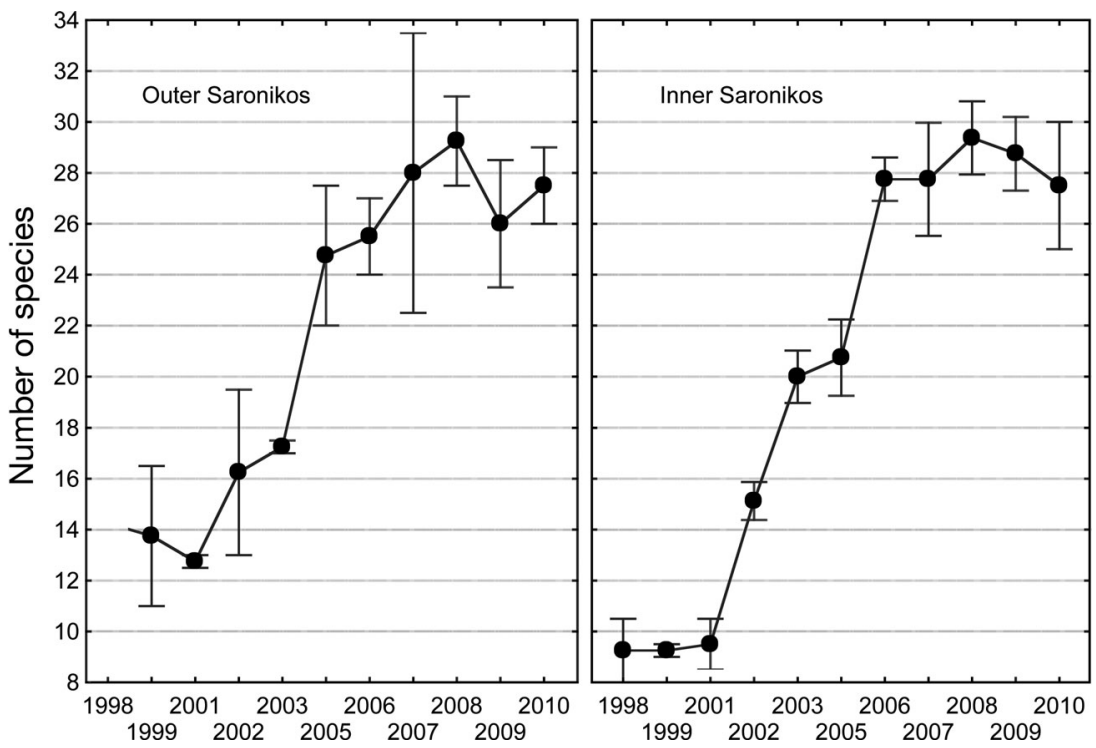

Fig. 3. Annual numbers of species per sampling unit for the outer and inner Saronikos Gulf. Means \pm SE

Table 2. One-way ANOVA examining differences among sampling years for the following parameters for the inner and outer Saronikos Gulf: number of species, total coverage, nitrophilous green algae (NGA) total coverage and total coverage of canopy brown algae (Cystoseira and Sargassum, CBA). All parameters are expressed per sampling unit. $\mathrm{p}<0.05$ (in bold) indicates a statistically significant difference between the mean parameter examined from one year to another at $95 \%$ confidence level

\begin{tabular}{|lccccc|}
\hline & Sum of squares & df & Mean squares & F-ratio & $p$ \\
\hline Inner Saronikos & & & & & \\
Number of species & 1957.7 & 10 & 195.8 & 21.7 & $<\mathbf{0 . 0 0 1}$ \\
Error & 244.1 & 27 & 9.0 & & \\
Cochran's test & 0.4 & & & & \\
Total coverage & 82407 & 10 & 8241 & 10.7 & $<\mathbf{0 . 0 0 1}$ \\
Error & 20828 & 27 & 771 & & \\
Cochran's test & 0.15 & & & & \\
NGA total coverage & 7889.5 & 10 & 789 & 3.6 & $\mathbf{0 . 0 0 4}$ \\
Error & 5950.8 & 27 & 220.4 & & \\
Cochran's test & 0.27 & & & & \\
CBA total coverage & 1608.3 & 10 & 160.8 & 0.6 & 0.778 \\
Error & 6932.9 & 27 & 256.8 & & \\
Cochran's test & 0.24 & & & & \\
Outer Saronikos & & & & & \\
Number of species & 839.6 & 10 & 84 & 6.5 & $\mathbf{0 . 0 0 2}$ \\
Error & 142.9 & 11 & 13 & & \\
Cochran's test & 0.60 & & & & \\
Total coverage & 56749.3 & 10 & 5675 & 12.0 & $<\mathbf{0 . 0 0 1}$ \\
Error & 5195.1 & 11 & 472.3 & & \\
Cochran's test & 0.38 & & & & \\
NGA total coverage & 1431.3 & 10 & 143.1 & 4.3 & $\mathbf{0 . 0 1 3}$ \\
Error & 367.9 & 11 & 33.4 & & \\
Cochran's test & 0.29 & & & & \\
CBA total coverage & 26763.5 & 10 & 2676 & 7.8 & $\mathbf{0 . 0 0 1}$ \\
Error & 3776.5 & 11 & 343.3 & & \\
Cochran's test & 0.68 & & & & \\
\hline
\end{tabular}

(Fig. 8, Table 2). At the inner sampling sites, the CBA species were already scarce in 1998, where they have remained at insignificant abundances ever since (Fig. 8, Table 2).

A detailed comparison of the phycocommunity structure and composition before and after 2004 revealed a significant alteration within the inner Saronikos region over time. Indeed, the NGA Ulva spp. and the geniculate red alga Corallina elongata, which had been the dominant species until 2004, decreased significantly after 2004 (Table 4). The basic community structure remained more or less the same, but with by far lower abundance of the dominant species and a much richer biodiversity. An alteration was also observed for the outer Saronikos region, where the originally dominant Cystoseira crinitophylla and Halopteris scoparia declined severely in coverage after 2004 (Table 4). Similarly to the inner region, the basic community structure remained about the same, but dominant species shifted to lower abundances.

Lastly, throughout the study area and period, 9 alien macroalgae were detected in the Saronikos Gulf (Table $\mathrm{S} 1$ in the supplement). However, all of these species were invariably characterised by rather low abundances at all studied sites and times.

\section{Nutrient gradients through time}

Nutrient concentration data show gradually, but significantly, decreasing levels of DIN for both the outer $\left(K_{12,97}=51.35, \mathrm{p}<0.001\right)$ and inner $\left(K_{12,109}=38.35, \mathrm{p}<0.001\right)$ part of the gulf, particularly after 2004 (Fig. 9). For SRP, a short-term increase was noticed between 2001 and 2004, followed immediately afterwards by a significant decrease for the outer gulf $\left(K_{12,97}=62.61, \mathrm{p}<0.001\right)$. In the inner part, an overall decrease was also noticed $\left(K_{12,109}=46.85, \mathrm{p}<0.001\right)$, especially after 2004 (Fig. 10). 

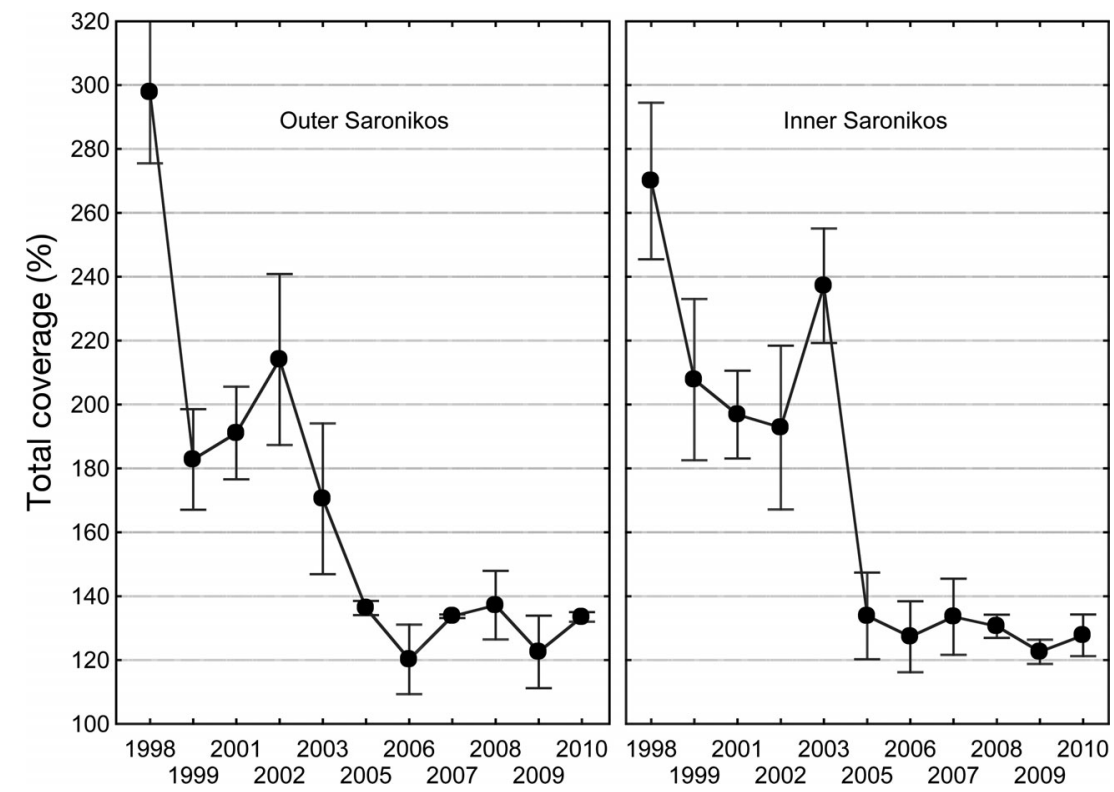

Fig. 4. Annual values of total coverage per sampling unit for the outer and inner Saronikos Gulf. Means \pm SE

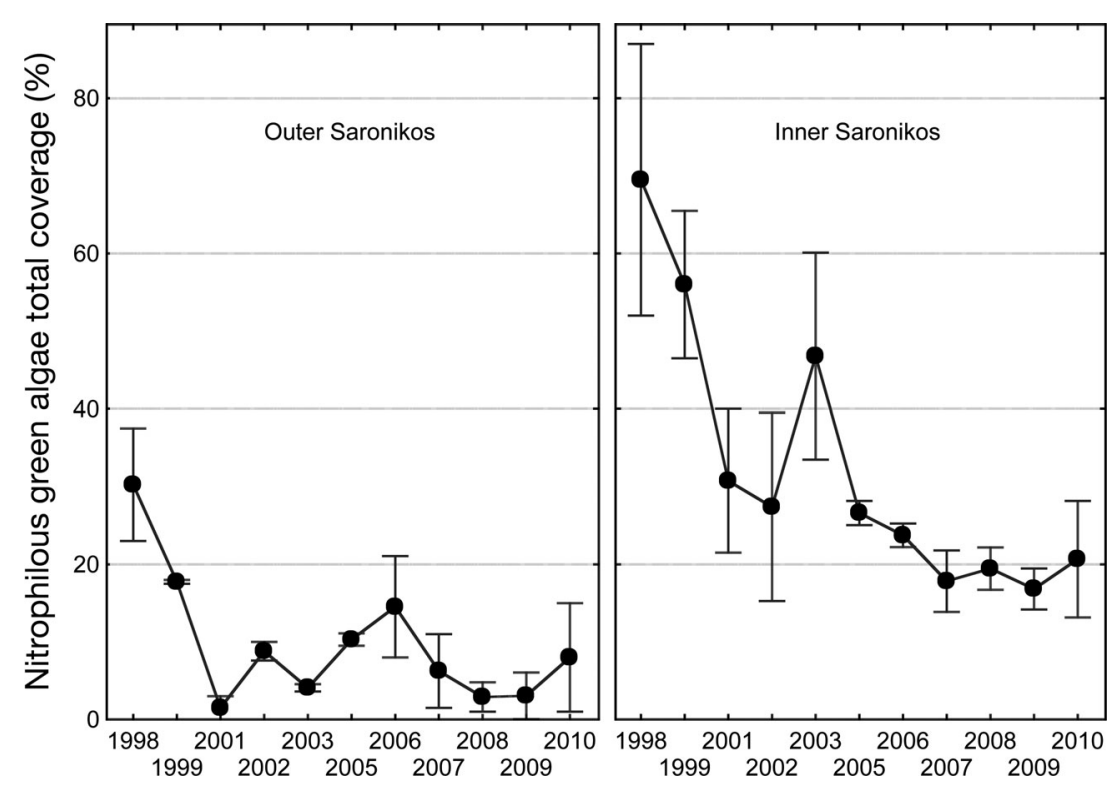

Fig. 5. Annual values of nitrophilous green algae (NGA) total coverage per sampling unit for the outer and inner Saronikos Gulf. Means \pm SE

\section{DISCUSSION}

Taking into account the fact that this study focuses strictly on the upper infralittoral zone of the Saronikos Gulf, and thus inevitably overlooks components of the deeper-water flora, this area seems to host a rather rich macroalgal biodiversity compared with other Eastern Mediterranean coasts (Mayhoub 1976, Haritonidis 1978, Chryssovergis 1995, Tsirika \& Haritonidis
2005). However, part of this may be accounted for by a much more intensive sampling and study effort rather than a genuine biogeographical variation (but see also Sales et al. 2012).

The gradual modification of the coastal environment of the Saronikos Gulf is reflected by intense alterations observed in the macroalgal populations, especially in the most impacted inner region of the gulf. The NGA gradually increased their abundance since the mid-1950s in the area (Diapoulis \& Haritonidis 1987), reflecting the growth of the Athenian agglomeration and its sewage output, which probably peaked in the mid-1990s when the Psittalia WWTP started operating. Conversely, the NGA decline since 1998 reveals a reversal of this trend, suggesting the onset of a reoligotrophication process, as also confirmed in this study through the declining nutrient levels (particularly in fterms of DIN levels) in surface waters. Following a short-term increase of SRP concentrations until 2004, possibly attributed to the increased sewage load and the still-lacking SRP capture, they decreased significantly afterwards.

The overall nutrient decrease in the area has led to a considerable improvement of the ecological quality of the gulf, thus confirming the effectiveness of the Psittalia WWTP in reducing nutrients in the gulf, and particularly so after the secondary treatment came into effect. Indeed, since 2004, both total nitrogen and total phosphorus levels of the water column have been reduced by 75 and $25 \%$, respectively (Pavlidou et al. 2008, Pavlidou \& Kapari 2010). Water mass circulation as well as the variation in flux of the sewage plume discharging in the inner Saronikos Gulf have played an important role in the nutrient dynamics and their gradients over time (Pavlidou et al. 2008). The statistically significant decrease of DIN and SRP has led to a shift in the surface water trophic state of the inner Saronikos, namely from upper mesotrophic to oligotrophic status, as assessed according to Karydis' (1999) water quality classification scale based on nutrient concentrations. 

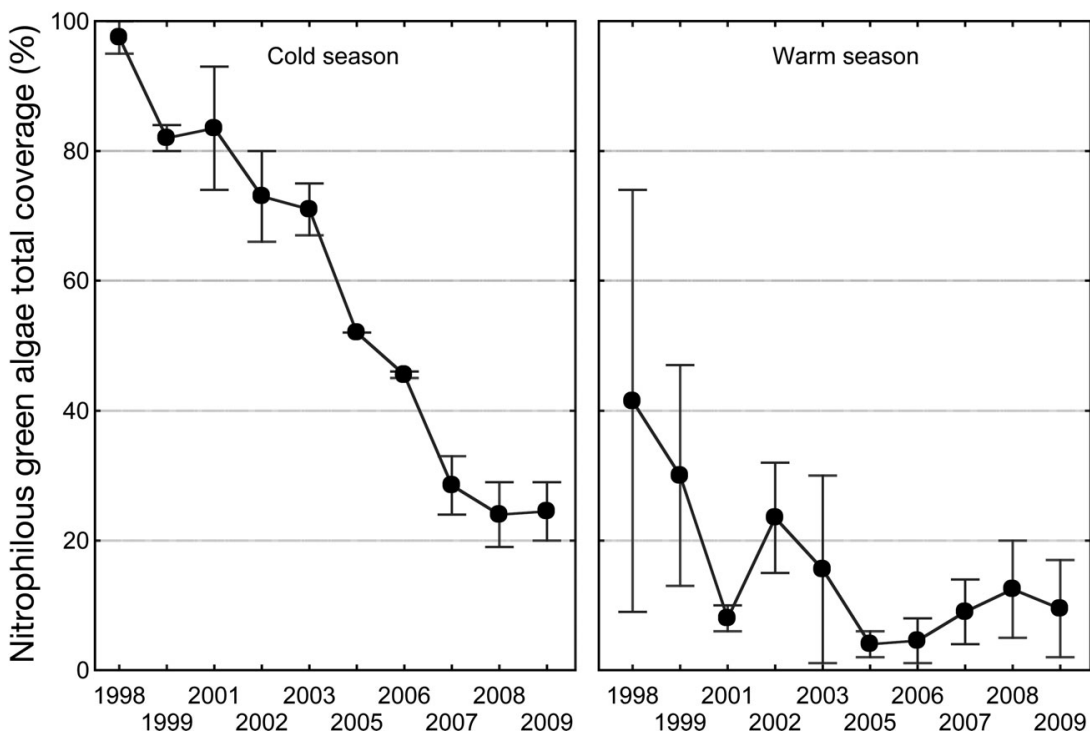

Fig. 6. Annual values of nitrophilous green algae (NGA) total coverage per sampling unit for the inner Saronikos Gulf for the cold (March) and warm (September) seasons. Means $\pm \mathrm{SE}$

Table 3. One-way ANOVA examining differences among sampling years of nitrophilous green algae (NGA) total coverage per sampling unit for the inner Saronikos Gulf. $\mathrm{p}<0.05$ (in bold) indicates a statistically significant difference between the annual mean NGA total coverage from one year to another at $95 \%$ confidence level

\begin{tabular}{|lccccc|}
\hline & Sum of squares & df & Mean squares & F-ratio & $\mathrm{p}$ \\
\hline Cold season & 13042.1 & 9 & 1449.1 & 31.3 & $\mathbf{< 0 . 0 0 1}$ \\
Error & 462.5 & 10 & 46.3 & & \\
Cochran's test & 0.82 & & & & \\
Warm season & 2689.9 & 9 & 298.9 & 0.8 & 0.6 \\
Error & 3567.4 & 10 & 356.7 & & \\
Cochran's test & 0.39 & & & & \\
\hline
\end{tabular}

The observed decline of the NGA presented intense seasonality, being more abrupt during the cold season (March) and milder during the warm season (September). This fact is probably related to the natural seasonal cycle of nitrophilous species, which are typically known to thrive in early spring, at times even forming extensive blooms, and decline again during summer (Lotze et al. 1999, Menendez \& Comin 2000, Scanlan et al. 2007).

The increased number of species is coherent with the overall decline of the NGA in the gulf. The lowdiversity nitrophilic communities, dominated mainly by Ulva spp., have been gradually decreasing and making space for a more diverse community, which hosts fewer nitrophilous seaweeds of lower total abundance. Indeed, this gradual alteration of the phyco-communities has favoured an increase in species richness, since numerous minute opportunistic and ephemeral species (mainly red algae of the order Ceramiales) took advantage of the new regime by claiming place in the novel community composition after 2004. Two years later, with the onset of secondary wastewater treatment, species numbers more or less stabilized.

The observed re-oligotrophication process may well explain the abrupt decrease of the total macroalgal coverage in the study area. Indeed, the considerable decline in NGA abundance and the gradual reversal from massive nitrophilous blooms to communities of less biomass but higher diversity have led to a sharp decrease of the overall algal coverage in the Saronikos Gulf over time. However, since 2005, total coverage values have somewhat stabilized, a fact consistent with the stabilizing conditions also reflected by the species richness fluctuation.

In view of the gulf's re-oligotrophication, the CBA Cystoseira and Sargassum spp., which are considered the emblematic species of the pristine Mediterranean coasts (Ballesteros et al. 2007, Pinedo et al. 2007, Mangialajo et al. 2008, Sales \& Ballesteros 2009), were expected to recover or at least stabilize in their abundance. In contrast, their populations have actually decreased, leading us to observe a paradox: not only did we document a major decline of Cystoseira and Sargassum coverage, but one much more pronouncedly expressed within the less impacted outer region of the gulf. The lack of CBA recovery in the inner region could be attributed to the pre-1998 scarcity of parental Cystoseira populations (Diapoulis \& Haritonidis 1987) or to the fact that this enclosed region may not yet have reached the water quality threshold required for recovery of these highly sensitive species. In constrast, the outer gulf, being more distant from the WWTP, had never been as heavily affected by organic and nutrient loads, a fact corroborated by the persistently low NGA abundances recorded here and especially so at the onset of the study period. Consequently, the decline of CBA species in the outer region cannot be directly attributed to the organic enrichment but rather to other causes. Such causes may include modification of the coastline through coastal works (e.g. the construction 

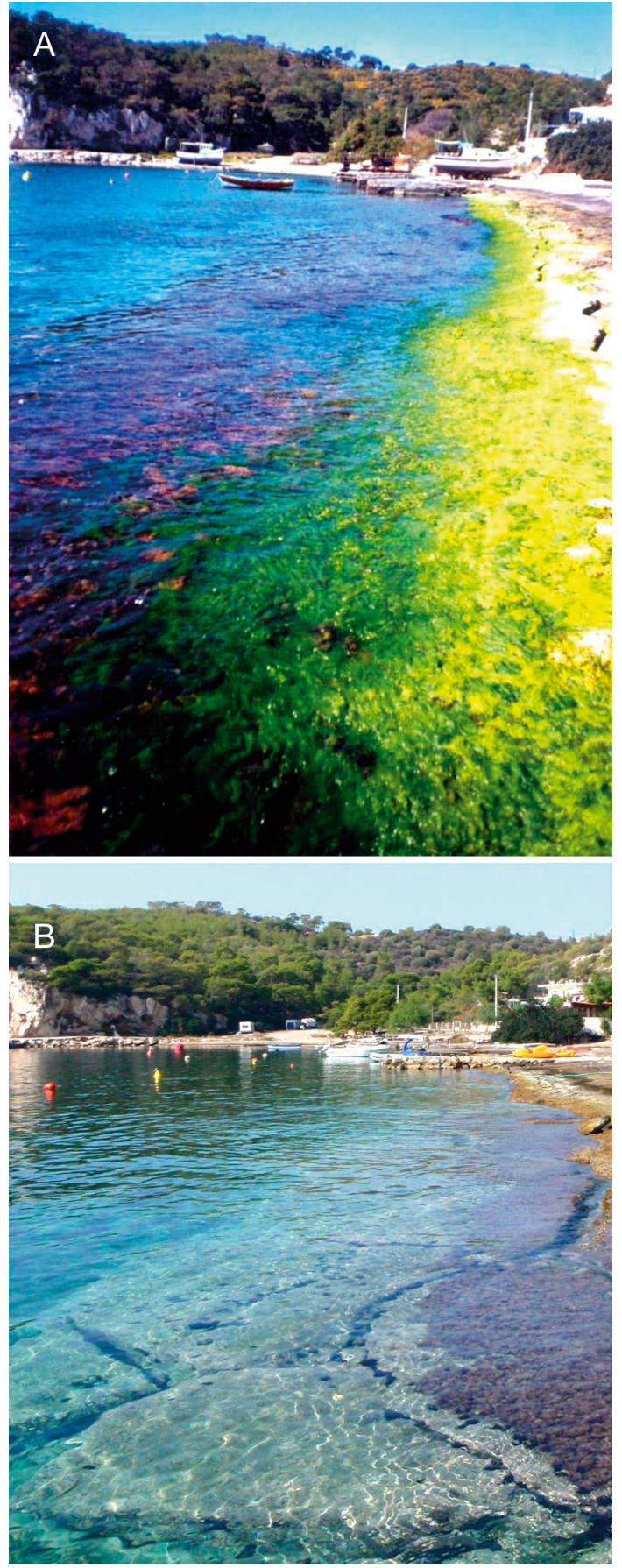

Fig. 7. The upper infralittoral zone of a rocky shore in Saronikos Gulf (Salamina coast) in (A) 1998 and (B) 2009

of sailing and other maritime sport facilities for the Athens 2004 Olympic Games, as well as numerous recreational buildings and installations), which have destroyed large parts of the natural habitats in the area (see also Sales \& Ballesteros 2009), or a potential increase in heavy metal and persistent organic compound concentrations in the seawater as reported
Table 4. Differences in abundance of major macroalgal species found before and after 2004 in the inner and outer Saronikos Gulf based on SIMPER analysis. The dissimilarity and the contribution (\%) of each taxon to overall dissimilarity are also given. Averaged values

\begin{tabular}{|c|c|c|c|c|}
\hline \multirow[t]{2}{*}{ Taxon } & \multicolumn{2}{|c|}{ Abundance } & \multirow{2}{*}{$\begin{array}{l}\text { Dis- } \\
\text { simi- } \\
\text { larity }\end{array}$} & \multirow{2}{*}{$\begin{array}{c}\text { Contrib. } \\
\qquad \%)\end{array}$} \\
\hline & $\begin{array}{l}\text { Before } \\
2004\end{array}$ & $\begin{array}{l}\text { After } \\
2004\end{array}$ & & \\
\hline \multicolumn{5}{|c|}{ Inner Saronikos: overall average dissimilarity $=\mathbf{7 9 . 1 4}$} \\
\hline Ulva spp. & 42.9 & 17.9 & $9.9^{1}$ & 12.5 \\
\hline Corallina elongata & 34.5 & 16.9 & 9.7 & 12.2 \\
\hline Jania rubens & 16.6 & 13.6 & 6.2 & 7.8 \\
\hline $\begin{array}{l}\text { Dictyopteris } \\
\text { polypodioides }\end{array}$ & 20.0 & 1.2 & 5.7 & 7.2 \\
\hline Cystoseira compressa & 5.3 & 8.6 & 3.8 & 4.8 \\
\hline Halopteris scoparia & 7.4 & 9.5 & 3.7 & 4.7 \\
\hline Sargassum vulgare & 6.8 & 5.6 & 2.9 & 3.7 \\
\hline Dictyota dichotoma & 1.8 & 8.4 & 2.6 & 3.3 \\
\hline Dictyota sp. & 9.9 & 0 & 2.4 & 3.1 \\
\hline Jania virgata & 6.5 & 0.5 & 1.9 & 2.5 \\
\hline Pterocladiella capillacea & 4.6 & 2.1 & 1.8 & 2.3 \\
\hline $\begin{array}{l}\text { Acanthophora } \\
\text { nayadiformis }\end{array}$ & 5.5 & 0.9 & 1.8 & 2.2 \\
\hline Schizymenia dubyi & 4.6 & 2.1 & 1.6 & 2.0 \\
\hline Hypnea musciformis & 3.6 & 3.1 & 1.4 & 1.8 \\
\hline Cystoseira crinitophylla & 4.9 & 0 & 1.4 & 1.8 \\
\hline Cladophora spp. & 3.4 & 2.9 & 1.4 & 1.8 \\
\hline Dictyota spiralis & 5.0 & 0.5 & 1.3 & 1.6 \\
\hline Padina pavonica & 4 & 1.3 & 1.2 & 1.54 \\
\hline Dictyota implexa & 2.3 & 2.0 & 1.2 & 1.5 \\
\hline Corallina officinalis & 0 & 3.1 & 0.9 & 1.2 \\
\hline \multicolumn{5}{|c|}{ Outer Saronikos: overall average dissimilarity $=67.45$} \\
\hline Cystoseira crinitophylla & 75.9 & 23.6 & 16.8 & 25 \\
\hline Jania rubens & 25.9 & 19.9 & 6.9 & 10.2 \\
\hline Halopteris scoparia & 15.5 & 3.3 & 4.2 & 6.2 \\
\hline Sargassum vulgare & 15.5 & 8.5 & 4.0 & 6.0 \\
\hline Cystoseira compressa & 12.3 & 9.7 & 3.2 & 4.7 \\
\hline Ulva spp. & 10.2 & 4.0 & 3.1 & 4.6 \\
\hline $\begin{array}{l}\text { Dictyopteris } \\
\text { polypodioides }\end{array}$ & 10.3 & 1.2 & 2.7 & 4.0 \\
\hline Padina pavonica & 5.3 & 7.6 & 1.9 & 2.9 \\
\hline Halopteris filicina & 3.5 & 2.2 & 1.7 & 2.5 \\
\hline $\begin{array}{l}\text { Caulerpa racemosa var. } \\
\text { cylindracea }\end{array}$ & 4.4 & 2.4 & 1.6 & 2.3 \\
\hline Dictyota dichotoma & 2.4 & 3.2 & 1.5 & 2.2 \\
\hline Cladophora spp. & 2.4 & 4.0 & 1.4 & 2.1 \\
\hline Schizymenia dubyi & 4.4 & 0.4 & 1.3 & 1.9 \\
\hline Jania virgata & 0.2 & 4.3 & 1.3 & 1.9 \\
\hline Cystoseira corniculata & 0 & 3.4 & 1.1 & 1.6 \\
\hline Laurencia obtusa & 2.5 & 0.3 & 0.9 & 1.3 \\
\hline Sphacelaria cirrosa & 1.2 & 1.7 & 0.8 & 1.2 \\
\hline Corallina elongata & 1.8 & 1.7 & 0.8 & 1.1 \\
\hline Halimeda tuna & 0.7 & 2.1 & 0.7 & 1 \\
\hline Colpomenia sinuosa & 1 & 1.6 & 0.6 & 0.9 \\
\hline
\end{tabular}

from several other coasts worldwide (Arévalo et al. 2007). More importantly, we would like to highlight the strong overgrazing pressures posed by dense (and probably increasing) populations of sea urchins and the Lessepsian herbivorous fishes Siganus spp. Even 

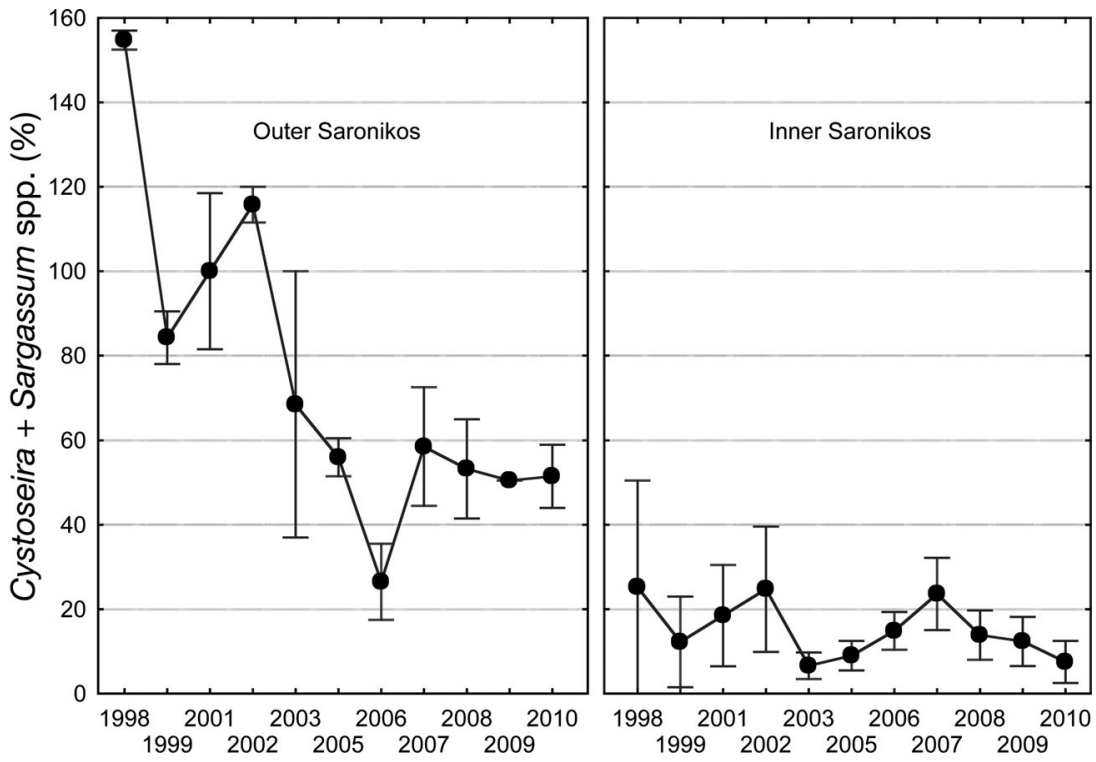

Fig. 8. Annual values of Cystoseira and Sargassum spp. (CBA) coverage per sampling unit for the outer and inner Saronikos Gulf. Means $\pm \mathrm{SE}$

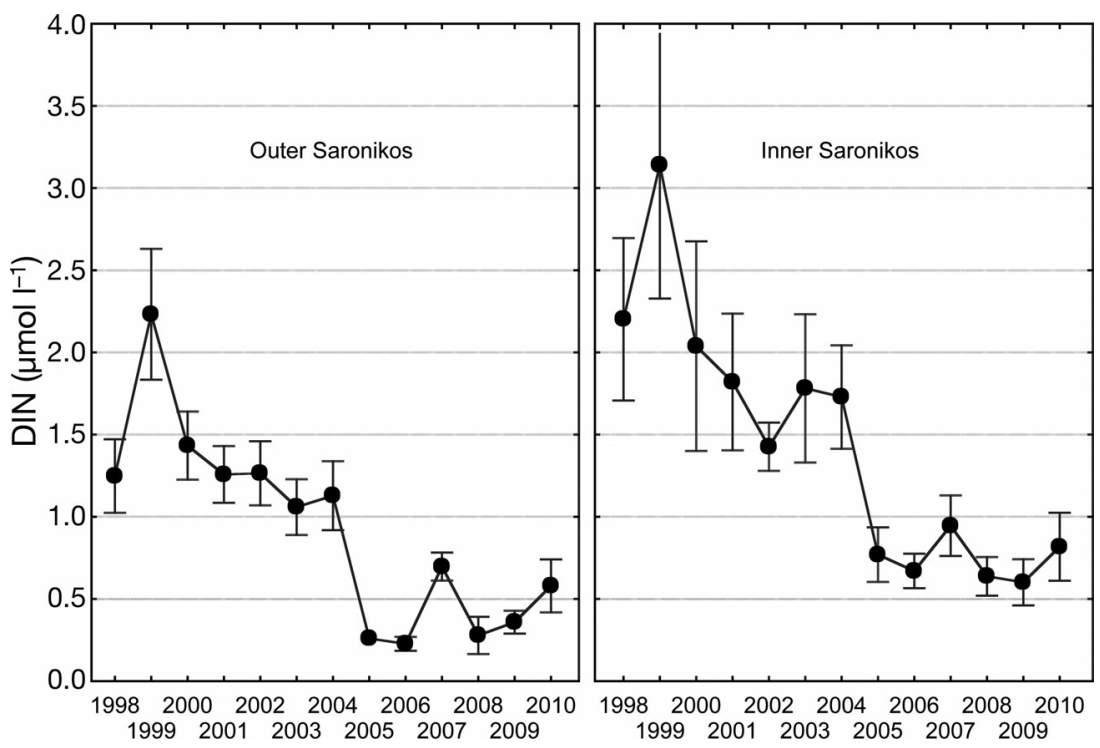

Fig. 9. Annual values of surface dissolved inorganic nitrogen (DIN) for the outer and inner Saronikos Gulf. Means \pm SE

though no quantitative data about sea urchin abundance are so far available for this region, our (as well as several recreational snorkelers' and divers') unpublished observations within the last decade do support this notion and allow for the hypothesis that increased sea urchin grazing has a major role in the decline of CBA species described here.

Moreover, sea urchin overpopulation is being increasingly recognized elsewhere as the primary cause of dramatic alterations in natural infralittoral communities (e.g. Coma et al. 2011) or even the complete removal of macroalgal canopies and the forma- tion of coralline barrens (e.g. Hereu et al. 2012 and references therein). This seems to present a growing threat for macroalgal communities, not only for the Saronikos Gulf as hereby suggested, but also for numerous other Greek (Pancucci \& Panayotidis 1994, authors' pers. obs.) and Mediterranean coasts (Hereu 2004, Thibaut et al. 2005, Thibaut et al. 2011; but see also Cardona et al. 2007, Giakoumi et al. 2011). Cases of sea urchin overpopulation are usually attributed to the removal of their key predator species (i.e. Sparidae and Labridae), e.g. through overfishing in heavily humanaffected areas (Harrold \& Reed 1985, Watanabe \& Harrold 1991, Vadas \& Steneck 1995, Sala et al. 1998, Steneck 1998, Valentine \& Johnson 2003). If this is indeed the case, without a widespread introduction of more sustainable fisheries practices there is little prospect for a sound control of sea urchin populations and recovery of the wider marine ecosystem in the area. In Greece, the sea urchin fishery has been legally restricted since the 1980s, when a disease outbreak almost wiped out their entire population. However, although sea urchin populations are nowadays fully recovered and thriving, these legal restrictions have not as yet been revised.

The Lessepsian fish species Siganus rivulatus and $S$. luridus have also been found to exert substantial pressure on macroalgal communities in places where these alien herbivores are highly abundant (Sala et al. 2011). However, in the Saronikos Gulf, these species are present yet in low abundances (authors' pers. obs.), but a likely increase in their population numbers could further add to the existing detrimental pressures on macroalgal communities, to the point of even eliminating any future chances of recovery.

As far as alien species are concerned, Saronikos Gulf may well be considered a hot-spot area as it hosts the highest number of alien seaweeds so far recorded along the Greek coast (K.T. unpubl. data). This finding is most likely due to the intense shipping activities around the Piraeus international port (Zenetos et al. 2011). However, the highly unstable 

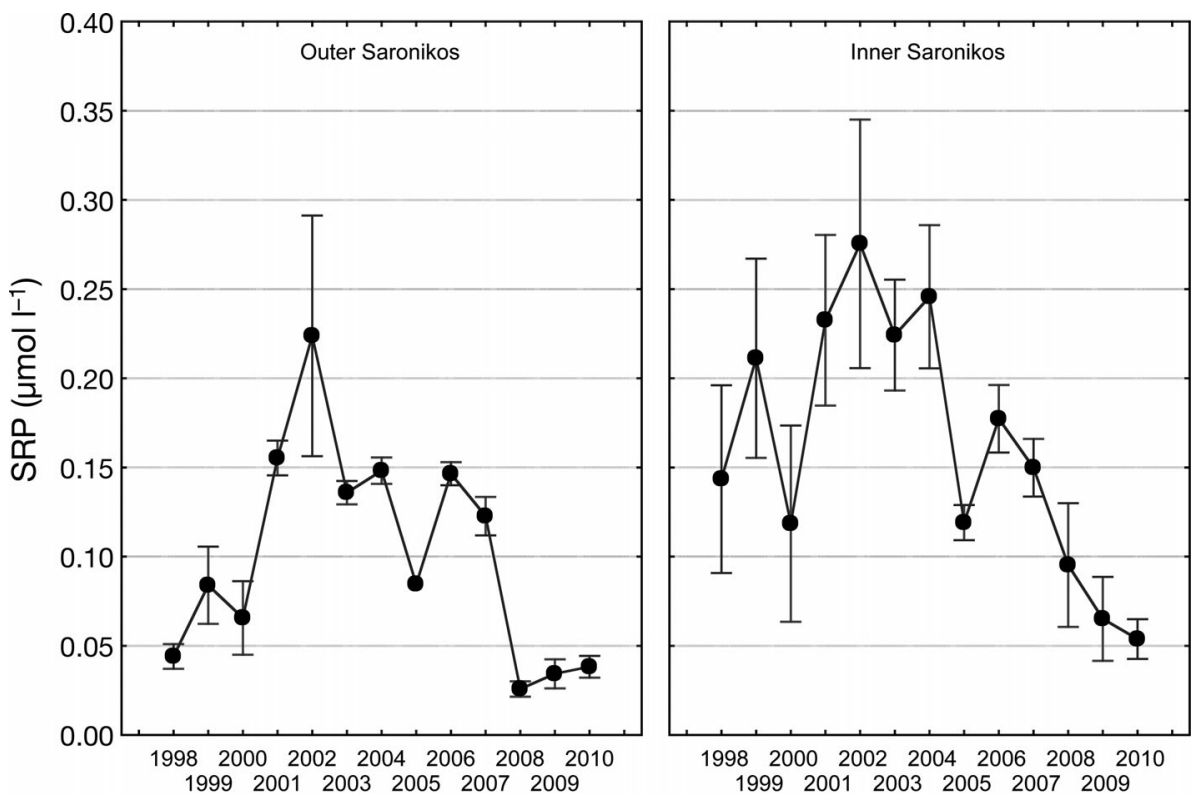

Fig. 10. Annual values of surface soluble reactive phosphorus (SRP) for the outer and inner Saronikos Gulf. Means \pm SE
After over a decade of the Psittalia WWTP operation, it seems that eutrophication no longer poses a serious threat to the marine vegetation of the Saronikos Gulf. However, the strong decline of Cystoseira and Sargassum spp. is of growing concern. Dealing with this issue seems of great importance, not only for our study area, but for the whole Mediterranean Sea.

In light of the shifting baselines problem in the assessment of ecosystems (Pauly 1995, Jackson et al. 2001), the present study once more underlines the value of historic data sets, e.g. as highlighted for coral reefs (Knowlton \& Jackson 2008) and coastal seaweed communities (Asensi \& Küpper 2012). conditions resulting from various and persistent anthropogenic disturbances, as well as the intense research effort invested in this area (compared with most other Greek and Mediterranean coasts), may also partly account for the high number of aliens recorded here. At any rate, none of these aliens - the notorious green alga Caulerpa racemosa var. cylindracea included (Klein \& Verlaque 2008) - were found to exhibit invasive potential, as their persistently low abundances can hardly be considered a threat to the native macroalgal communities of the shallow infralittoral Saronikos coasts. Deeper habitats, however, where alien macroalgae are often more abundant (Ruitton et al. 2005, Cebrian \& Ballesteros 2010), are rather poorly studied in the area (but see Katsanevakis et al. 2010), so possible invasions by alien macroalgae should not be entirely ruled out.

\section{CONCLUSIONS}

Overall, our study revealed a gradual re-oligotrophication process of the coastal marine ecosystem of the Saronikos Gulf after the establishment of the Psittalia WWTP in the area. This process was reflected by a general decline of the total inshore benthic vegetation coverage, especially for Ulva species, but also by a sharp decrease in DIN levels. This seems to have considerably enhanced the macroalgal biodiversity in the upper infralittoral zone of the study area.
Acknowledgements. We thank the Athens Water Supply and Sewerage Company (EYDAP SA) for funding and support this study. We are also grateful to the Greek Ministry of Environment, the TOTAL Foundation (Paris; Project 'Brown algal biodiversity and ecology in the Eastern Mediterranean Sea') and the UK Natural Environment Research Council (Oceans 2025/WP4.5 core funding to F.C.K. at Scottish Association for Marine Science) for funding different aspects of this study.

\section{LITERATURE CITED}

Arévalo R, Pinedo S, Ballesteros E (2007) Changes in the composition and structure of Mediterranean rocky-shore communities following a gradient of nutrient enrichment: descriptive study and test of proposed methods to assess water quality regarding macroalgae. Mar Pollut Bull 55:104-113

Asensi AO, Küpper FC (2012) Seasonal periodicity and reproduction of brown algae (Phaeophyta) at Puerto Deseado (Patagonia). Bot Mar 55:217-228

Ballesteros E, Torras X, Pinedo S, Garcia M, Mangialajo L, de Torres M (2007) A new methodology based on littoral community cartography dominated by macroalgae for the implementation of the European Water Framework Directive. Mar Pollut Bull 55:172-180

Belsher T (1977) Analyse des répercussions des pollutions urbaines sur le macrophytobenthos de la Méditerranée (Marseille, Port-Ventres, Port-Cros). PhD thesis, Université d'Aix-Marseille II

Bianchi CN, Morri C (2000) Marine biodiversity of the Mediterranean Sea: situation, problems and prospects for future research. Mar Pollut Bull 40:367-376

Boudouresque CF, Belsher T (1979) Le peuplement algal du port de Port-Vendres: recherches sur l'air minimal qualitative. Cah Biol Mar 20:259-269 
Brown VB, Davies SA, Synnot RN (1990) Long-term monitoring of the effects of treated sewage effluent on the intertidal macroalgal community near Cape Schanck, Australia. Bot Mar 33:85-98

$>$ Cardona L, Sales M, Lopez D (2007) Changes in fish abundance do not cascade to sea urchins and erect algae in one of the most oligotrophic parts of the Mediterranean. Estuar Coast Shelf Sci 72:273-282

Cebrian E, Ballesteros E (2010) Invasion of Mediterranean benthic assemblages by red alga Lophocladia lallemandii (Montagne) F. Schmitz: depth-related temporal variability in biomass and phenology. Aquat Bot 92: 81-85

Chryssovergis B (1995) L'impact de l'eutrophisation sur les algues benthiques (Chlorophyceae, Fucophyceae, Rhodophyceae) de l'infralittoral supérieur du Golfe de Maliakos (Mer Egée, Grèce). PhD thesis, Université d'AixMarseille II

Coll M, Piroddi C, Steenbeek J, Kaschner K and others (2010) The biodiversity of the Mediterranean Sea: estimates, patterns, and threats. PLoS ONE 5(8):e11842

Coma R, Serrano E, Linares C, Ribes M, Díaz D, Ballesteros E (2011) Sea urchins predation facilitates coral invasion in a marine reserve. PLoS ONE 6(7):e22017

Dhont F, Coppejans E (1977) Résultats d'une étude d'aire minima des peuplements algaux photophiles sur substrat rocheux à Port-Cros et à Banyuls (France). Rapport CIESM 24:141-142

Diapoulis A, Haritonidis S (1987) A qualitative and quantitative study of the marine algae in the Saronikos Gulf (Greece). PSZNI: Mar Ecol 8:175-189

Diez I, Secilla A, Santolaria A, Gorostiaga JM (1999) Phytobenthic intertidal community structure along an environmental pollution gradient. Mar Pollut Bull 38:463-472

> Diez I, Santolaria A, Secilla A, Gorostiaga JM (2009) Recovery stages over long-term monitoring of the intertidal vegetation in the 'Abra de Bilbao' area and on the adjacent coast (N. Spain). Eur J Phycol 44:1-14

Giakoumi S, Cebrian E, Kokkoris GD, Ballesteros E, Sala E (2011) Relationships between fish, sea urchins and macroalgae: the structure of shallow rocky sublittoral communities in the Cyclades, Eastern Mediterranean. Estuar Coast Shelf Sci 109:1-10

Guiry MD, Guiry GM (2011) Algaebase. National University of Ireland, Galway

> Haritonidis S (1978) A survey of the marine algae of Thermaikos Gulf, Thessaloniki, Greece. I. Distribution and seasonal periodicity. Bot Mar 21:527-535

Harrold C, Reed DC (1985) Food availability, sea urchin grazing, and kelp forest community structure. Ecology 66:1160-1169

Hereu B (2004) The role of trophic interactions between fishes, sea urchins and algae in the northwestern Mediterranean rocky infralittoral. University of Barcelona, Barcelona

Hereu B, Linares C, Sala E, Garrabou J, Garcia-Rubies A Diaz D, Zabala M (2012) Multiple processes regulate long-term population dynamics of sea urchins on Mediterranean rocky reefs. PLoS ONE 7 (5):e36901

> Hereu B, Mangialajo L, Enric B, Thibaut T (2008) On the occurrence, structure and distribution of deep-water Cystoseira (Phaeophyceae) populations in the Port-Cros National Park (Northwestern Mediterranean). Eur J Phycol 43:263-273

Hoffman L, Clarisse S, Detienne X, Goffart A, Renard R,
Demoulin V (1988) Evolution of the populations of Cystoseira balearica (Phaeophycae) and epiphytic Bangiophyceae in the Bay of Calvi (Corsica) in the last eight years. Bull Soc R Liège 4-5:263-273

> Jackson JBC, Kirby MX, Berger WH, Bjorndal KA and others (2001) Historical overfishing and the recent collapse of coastal ecosystems. Science 293:629-637

Karydis M (1999) Evaluation of the trophic levels in Greek coastal ecosystems. University of the Aegean, Mytilene

Katsanevakis S, Salomidi M, Panou A (2010) Modelling distribution patterns and habitat preference of the invasive green alga Caulerpa racemosa in the Saronikos Gulf (Eastern Mediterranean). Aquat Biol 10:57-67

Klein J, Verlaque M (2008) The caulerpa racemosa invasion: a critical review. Mar Pollut Bull 56:205-225

Knowlton N, Jackson JBC (2008) Shifting baselines, local impacts, and global change on coral reefs. PLoS Biol 6: e54

Koroleff F (1970) Direct determination of ammonia in natural waters as indophenol blue. Information on techniques and methods for seawater analysis. Inter-lab Rep Cons Int Explor Mer 3:19-22

Littler MM, Murray SN (1975) Impact of sewage on the distribution, abundance and community structure of rocky intertidal macro-organisms. Mar Biol 30:277-291

Lotze HK, Schramm W, Schories D, Worm B (1999) Control of macroalgal blooms at early developmental stages: Pilayella littoralis versus Enteromorpha spp. Oecologia 119:46-54

Makra A, Thessalou-Legaki M, Costelloe J, Nicolaidou A, Keegan BF (2001) Mapping the pollution gradient of the Saronikos Gulf benthos prior to the operation of the Athens sewage treatment plant, Greece. Mar Pollut Bull 42:1417-1419

> Mangialajo L, Chiantore M, Cattaneo-Vietti R (2008) Loss of fucoid algae along a gradient of urbanisation, and structure of benthic assemblages. Mar Ecol Prog Ser 358: 63-74

Mayhoub H (1976) Recherches sur la végétation marine de la côte syrienne. Etude expérimentale sur la morphogenèse et le développement de quelques espèces peu connues. PhD thesis, Université de Caen

> Menendez M, Comin FA (2000) Spring and summer proliferation of floating macroalgae in a Mediterranean coastal lagoon (Tancada Lagoon, Ebro Delta, Ne Spain). Estuar Coast Shelf Sci 51:215-226

Munda IM, Veber M (1996) Simultaneous effects of trace metals and excess nutrients on the Adriatic seaweed Fucus virsoides (Don.) J. Ag. (Phaeophyceae, Fucales). Bot Mar 39:297-309

Murphy J, Riley JP (1962) A modified single solution method for the determination of phosphate in natural waters. Anal Chim Acta 27:31-36

Orfanidis S, Panayotidis P, Stamatis N (2001) Ecological evaluation of transitional and coastal waters: a marine benthic macrophytes-based model. Medit Mar Sci 2: 45-65

Orfanidis S, Panayotidis P, Ugland K (2011) Ecological Evaluation Index continuous formula (EEI-c) application: a step forward for functional groups, the formula and reference condition values. Medit Mar Sci 12:199-231

Orlando-Bonaca M, Lipej L, Orfanidis S (2008) Benthic macrophytes as a tool for delineating, monitoring and assessing ecological status: the case of Slovenian coastal waters. Mar Pollut Bull 56:666-676 
Panayotidis P, Montesantou B, Orfanidis S (2004) Use of lowbudget monitoring of macroalgae to implement the European Water Framework Directive. J Appl Phycol 16: 49-59

Pancucci MA, Panayotidis P (1994) Impact of eutrophication on sea-urchin populations of the Amvrakikos Gulf (Ionian sea, Greece). In: UNEP/FAO: Final reports on research projects dealing with eutrophication problems. MAP Tech Rep Ser No. 78. UNEP, Athens

Pauly D (1995) Anecdotes and the shifting baseline syndrome of fisheries. Trends Ecol Evol 10:430

Pavlidou A, Kapari M (2010) Nutrients in transitional, coastal and marine waters. Report of streamlining European biodiversity indicators, Vol 15. Hellenic Centre for Marine Research, Athens, p 8

Pavlidou A, Kontoyiannis H, Psyllidou-Giouranovits R (2008) Nutrient concentrations in the inner Saronikos Gulf after the sewage secondary treatment. Fresenius Environ Bull 17:1852-1858

Pérès JM, Picard J (1956) Recherches sur les peuplements benthiques de la Méditerranée Nord-Orientale. Résultats scientifiques des campagnes de la Calypso. Ann Inst Oceanogr NS 34:213-291

Pérès JM, Picard J (1964) Nouveau manuel de bionomie benthique de la Mer Méditerranée. Recl Trav Stn Mar Endoume 31:3-137

Pergent G (1991) Les indicateurs écologiques de la qualité du milieu marin en Mediterranée. Oceanis 17:341-350

Pinedo S, Garcia M, Satta MP, de Torres M, Ballesteros E (2007) Rocky-shore communities as indicators of water quality: a case study in the northwestern Mediterranean. Mar Pollut Bull 55:126-135

Roberts M (1978) Active speciation in the taxonomy of the genus Cystoseira C. Ag. In: Irvine DEG, Price JH (eds) Modern approaches to the taxonomy of red and brown algae. Academic Press, London, p 399-422

Rodriguez-Prieto C, Polo L (1996) Effects of sewage pollution in the structure and dynamics of the community of Cystoseira mediterranea (Fucales, Phaeophyceae). Sci Mar 60:253-263

Ruitton S, Javel F, Culioli JM, Meinesz A, Pergent G, Verlaque M (2005) First assessment of the Caulerpa racemosa (Caulerpales, Chlorophyta) invasion along the French Mediterranean coast. Mar Pollut Bull 50:1061-1068

Sala E, Boudouresque CF, Harmelin-Vivien M (1998) Fishing, trophic cascades, and the structure of algal assemblages: Evaluation of an old but untested paradigm. Oikos 82:425-439

Sala E, Kizilkaya Z, Yildirim D, Ballesteros E (2011) Alien marine fishes deplete algal biomass in the eastern Mediterranean. PLoS ONE 6:e17356

Sales M, Ballesteros E (2009) Shallow Cystoseira (Fucales: Ochrophyta) assemblages thriving in sheltered areas from Menorca (NW Mediterranean): relationships with environmental factors and anthropogenic pressures. Estuar Coast Shelf Sci 84:476-482

Sales M, Ballesteros E, Anderson MJ, Ivesa L, Cardona E (2012) Biogeographical patterns of algal communities in the Mediterranean Sea: Cystoseira crinita-dominated assemblages as a case study. J Biogeogr 39:140-152

Scanlan CM, Foden J, Wells E, Best MA (2007) The monitoring of opportunistic macroalgal blooms for the Water Framework Directive. Mar Pollut Bull 55:162-171
Silva PC (2011) Index nominum algarum. http://ucjeps. berkeley.edu/INA.html (accessed 24 Aug 2012)

Simboura N, Panayotidis P, Papathanassiou E (2005) A synthesis of the biological quality elements for the implementation of the European Water Framework Directive in the Mediterranean ecoregion: the case of Saronikos Gulf. Ecol Indic 5:253-266

Soltan D, Verlaque M, Boudouresque CF, Francour P (2001) Changes in macroalgal communities in the vicinity of a Mediterranean sewage outfall after the setting up of a treatment plant. Mar Pollut Bull 42:59-70

Steneck RS (1998) Human influences on coastal ecosystems: Does overfishing create trophic cascades? Trends Ecol Evol 13:429-430

> Steneck RS, Graham MH, Bourque BJ, Corbett D, Erlandson JM, Estes JA, Tegner MJ (2002) Kelp forest ecosystems: biodiversity, stability, resilience and future. Environ Conserv 29:436-459

Strickland JDH, Parsons TR (1977) A practical handbook of seawater analysis. Fish Res Board Can Bull 167:1-320

Tewari A, Joshi HV (1988) Effect of domestic sewage and industrial effluents on biomass and species diversity of seaweeds. Bot Mar 1988:389-397

Thibaut T, Pinedo S, Torras X, Ballesteros E (2005) Long-term decline of the populations of Fucales (Cystoseira spp. and Sargassum spp.) in the Albères coast (France, Northwestern Mediterranean). Mar Pollut Bull 50:1472-1489

Thibaut T, Blanfune A, Lorraine B, Markovic L, Meinesz A, Robvieux P (2011) Evaluation of the Fucales populations on the French Mediterranean coast. 5th European Phycological Congress. Taylor \& Francis, Rhodes, p 75

Tsiamis K, Montesanto B, Panayotidis P, Katsaros C, Verlaque $M$ (2010) Updated records and range expansion of alien marine macrophytes in Greece (2009). Medit Mar Sci 11:61-79

Tsirika A, Haritonidis S (2005) A survey of the benthic flora in the national marine park of Zakynthos (Greece). Bot Mar 48:38-45

Vadas RL, Steneck RS (1995) Overfishing and inferences in kelp-sea urchin interactions. In: Skjoldal HR, Valentine JP, Johnson CR (eds) Ecology of fjords and coastal waters. Elsevier, Amsterdam, p 509-524

> Valentine JP, Johnson CR (2003) Establishment of the introduced kelp Undaria pinnatifida in Tasmania depends on disturbance to native algal assemblages. J Exp Mar Biol Ecol 295:63-90

Verlaque M (1987) Contribution a l'étude du phytobenthos d'un ecosystem photophile thermophile en Mediterraneé occidental. PhD thesis, Université d'Aix-Marseille II

- Watanabe JM, Harrold C (1991) Destructive grazing by sea urchins Strongylocentrotus spp. in a central Californian kelp forest: potential roles of recruitment, depth, and predation. Mar Ecol Prog Ser 71:125-141

Williams SH, Smith JE (2007) A global review of the distribution, taxonomy, and impacts of introduced seaweeds. Annu Rev Ecol Evol Syst 38:327-359

Xenarios S (2009) Valuation of environmental impacts in water resources: the European experience. PhD thesis, Panteion University, Athens

Zenetos A, Katsanevakis S, Poursanidis D, Crocetta F, and others (2011) Marine alien species in Greek Seas: additions and amendments by 2010. Medit Mar Sci 129: 95-120 